\title{
Simple HPLC-UV Analysis of Phenol and Its Related Compounds in Tap Water after Pre-Column Derivatization with 4-Nitrobenzoyl Chloride
}

\author{
Yasuhiko Higashi \\ Department of Analytical Chemistry, Faculty of Pharmaceutical Sciences, Hokuriku University, Kanazawa, Japan \\ Email: y-higashi@hokuriku-u.ac.jp
}

How to cite this paper: Higashi, Y. (2017) Simple HPLC-UV Analysis of Phenol and Its Related Compounds in Tap Water after Pre-Column Derivatization with 4-Nitrobenzoyl Chloride. Journal of Analytical Sciences, Methods and Instrumentation, 7, 18-28.

https://doi.org/10.4236/jasmi.2017.71002

Received: January 13, 2017

Accepted: March 26, 2017

Published: March 29, 2017

Copyright $\odot 2017$ by author and Scientific Research Publishing Inc. This work is licensed under the Creative Commons Attribution International License (CC BY 4.0).

http://creativecommons.org/licenses/by/4.0/

\begin{abstract}
The purpose of this study is to develop an HPLC-UV $(280 \mathrm{~nm})$ method for simultaneous determination of phenol, five chlorophenols (2-chlorophenol, 4-chlorophenol, 2,4-dichlorophenol, 2,6-dichlorophenol, and 2,4,6-trichlorophenol), and three phenylphenols (2-phenylphenol, 3-phenylphenol, and 4-phenylphenol) in tap water after pre-column derivatization with 4-nitrobenzoyl chloride. Standard curves were obtained after derivatization with 4-nitrobenzoyl chloride in borate buffer $(\mathrm{pH} 8.5)$ at $50^{\circ} \mathrm{C}$ for $1 \mathrm{~min}$. The nine 4-nitrobenzoyl derivatives were well separated in less than $15 \mathrm{~min}$ on a Cholester column. Calibration plots were linear in the range of $0.02 \sim 0.12$ to 0.9 $\mathrm{mg} / \mathrm{L}$, with $r^{2}$ values $\geq 0.9928$, for all compounds. The lower limits of detection were 0.006 to $0.05 \mathrm{mg} / \mathrm{L}$. The coefficients of variation were less than $12.0 \%$. The recovery values from tap water spiked with a standard mixture of test compounds were satisfactory. While the levels of phenol, five chlorophenols, and three phenylphenols in tap water were below the lower limit of determination, our method is expected to be useful for monitoring and/or identifying environmental water samples that are contaminated with these compounds, i.e., for assessing compliance with the official guidelines of the World Health Organization.
\end{abstract}

\section{Keywords}

Phenol, Chlorophenol, Phenylphenol, 4-Nitrobenzoyl Chloride, Derivatization

\section{Introduction}

Phenol is present as a pollutant in the aquatic environment because of its widespread use for the synthesis of dyes and drugs, and its presence in various 
commercial products. Chlorophenols (2-chlorophenol, 2-CP; 4-chlorophenol, 4-CP; 2,4-dichlorophenol, 2,4-DCP; 2,6-dichlorophenol, 2,6-DCP; and 2,4,6trichlo-rophenol, 2,4,6-TCP) are malodorous even at very low concentrations in the aquatic environment, and may be present in drinking water as a result of disinfection processes employing chlorination, which result in chlorination at the $o$ - and/or $p$ - position(s) of phenol, if it is present. These compounds may also be formed by the reaction of hypochlorite with phenolic acids and during the degradation of phenoxy herbicides [1]. The World Health Organization (WHO) guideline value for $2,4,6-\mathrm{TCP}$ is $0.2 \mathrm{mg} / \mathrm{L}$, and concentrations of CPs in drinking-water are usually less than $0.001 \mathrm{mg} / \mathrm{L}$ [1]. The maximum permissible level of total phenols is $0.5 \mathrm{mg} / \mathrm{L}$ in drinking water, and the concentrations of individual phenols must not exceed $0.1 \mathrm{mg} / \mathrm{L}$ according to the United States Environmental Protection Agency and the European Union regulations [2] [3] [4]. On the other hand, the maximum permissible level of total phenols is less than $0.005 \mathrm{mg} / \mathrm{L}$ in drinking and tap water and less than $5 \mathrm{mg} / \mathrm{L}$ in industrial waste water according to the Japanese Water Pollution Control Law.

Since 2-phenylphenol (2-PP) has activities as a disinfectant, bactericide, and virucide, it is used in households, industry, and hospitals to disinfect surfaces and is also utilized as a preservative in cosmetics, plastics, etc. [5] [6]. 2-PP exhibits low acute toxicity in animal experiments [7]. The Japanese government approved its use as a food additive only for citrus fruits in 1977 with the permitted maximum residue level of $10 \mathrm{ppm}$ in whole fruits [8] [9]. The WHO view on the toxicity of 2-PP is as follows [10]: "A health-based value of $1 \mathrm{mg} / \mathrm{L}$ can be calculated for 2-PP on the basis of an ADI of $0.4 \mathrm{mg} / \mathrm{kg}$ of body weight, based on a NOAEL of $39 \mathrm{mg} / \mathrm{kg}$ of body weight per day in a 2-year toxicity study for decreased body weight gain and hyperplasia of the urinary bladder and carcinogenicity of the urinary bladder in male rats, using an uncertainty factor of 100 . Because of its low toxicity, however, the health-based value derived for 2-PP is much higher than 2-PP concentrations likely to be found in drinking-water. Under usual conditions, therefore, the presence of 2-PP in drinking-water is unlikely to represent a hazard to human health."

One of the most widely used methods for determination of total phenols in water samples is visible absorbance measurement following reaction with 4aminoantipyrine [11] [12]. However, this method can not determine the concentrations of individual phenols. Various separation methods for detection of the phenols described above have been reported, employing GC, HPLC, and capillary electrophoresis with various detection modes, including fluorimetry, mass spectrometry, chemiluminescence, and electrochemical analysis [13]-[18]. Derivatization with a UV-absorbing or fluorescent agent is one of the most useful techniques to improve selectivity and sensitivity, and may make sample clean-up unnecessary. Various reagents such as benzoyl chloride [4], 4-fluoro-7nitro-2,1,3,-benzoxadiazole [19], 4-(4,5-diphenyl-1 $H$-imidazol-2-yl) benzoyl chloride [20], coumarin-6-sulfonyl chloride [16], dansyl chloride [21], 2-(9- 
carbazole) ethyl chloroformate [22], and 3-chlorocarbonyl-6,7-dimethoxy-1methyl-2(1H)-quinoxalinone [23] have been used for analysis of phenol and/or CPs in biological, food, and environmental samples by means of HPLC with UV or fluorescence detection.

Various reagents such as 4-fluoro-7-nitro-2,1,3,-benzoxadiazole [24] and 4-( $N$-chloroformylmethyl- $N$-methylamino)-7-nitro-2,1,3-benzoxadiazole [25] have been used for analysis of PPs in cosmetic and environmental samples by means of HPLC with UV and fluorescence detection, respectively. Yang et al. developed a highly sensitive method of 2-PP determination by HPLC with electrochemical detection, using a microbore column; this afforded a detection limit of $3.4 \mathrm{pg}$ [9]. GC-mass spectrometry methods for determination of 2-PP after derivatization with pentafluorobenzoyl bromide and ferrocenecarboxylic acid chloride were applied to beer and citrus fruit samples, respectively [5] [6]. On the other hand, the WHO does not set guideline values for two positional isomers of 2-PP, 3-phenylphenol (3-PP) and 4-phenylphenol (4-PP), and no method has been reported for assay of 3-PP or 4-PP. While the previous method employing HPLC-UV after derivatization with 4-fluoro-7-nitro-2,1,3,-benzoxadiazole was simple, the reagent is expensive and the system was not applicable for the analysis of PPs, but only phenol and five CPs.

In this paper, we present a simple HPLC-UV method for simultaneous determination of phenol, five CPs (2-CP, 4-CP, 2,4-DCP, 2,6-DCP, and 2,4,6-TCP), and three PPs (2-PP, 3-PP, and 4-PP) in tap water after pre-column derivatization with 4-nitrobenzoyl chloride $(4-\mathrm{NB}-\mathrm{Cl})$. The derivatization scheme is shown in Figure 1.

\section{Materials and Methods}

\subsection{Materials}

Phenol, 2-CP, 4-CP, 2,4-DCP, 2,6-DCP, 2,4,6-TCP, and general reagents were obtained from Wako Pure Chemical Industries (Osaka, Japan). 2-PP and 4-PP were purchased from Kanto Chemical Co., Inc. (Tokyo, Japan). 3-PP and 4-NB-Cl were obtained from Tokyo Chemical Industry Co., Ltd. (Tokyo). Tap

Phenol, five CPs, and three PPs

\begin{tabular}{ll} 
Phenol & $\mathrm{R}_{1}=\mathrm{R}_{2}=\mathrm{R}_{3}=\mathrm{R}_{4}=\mathrm{R}_{5}=\mathrm{H}$ \\
$2-\mathrm{CP}$ & $\mathrm{R}_{1}=\mathrm{Cl}, \mathrm{R}_{2}=\mathrm{R}_{3}=\mathrm{R}_{4}=\mathrm{R}_{5}=\mathrm{H}$ \\
4-CP & $\mathrm{R}_{1}=\mathrm{R}_{2}=\mathrm{R}_{4}=\mathrm{R}_{5}=\mathrm{H}, \mathrm{R}_{3}=\mathrm{Cl}$ \\
$2,4-\mathrm{DCP}$ & $\mathrm{R}_{1}=\mathrm{R}_{3}=\mathrm{Cl}, \mathrm{R}_{2}=\mathrm{R}_{4}=\mathrm{R}_{5}=\mathrm{H}$ \\
$2,6-\mathrm{DCP}$ & $\mathrm{R}_{1}=\mathrm{R}_{5}=\mathrm{Cl}, \mathrm{R}_{2}=\mathrm{R}_{3}=\mathrm{R}_{4}=\mathrm{H}$ \\
$2,4,6-\mathrm{TCP}$ & $\mathrm{R}_{1}=\mathrm{R}_{3}=\mathrm{R}_{5}=\mathrm{Cl}, \mathrm{R}_{2}=\mathrm{R}_{4}=\mathrm{H}$ \\
2-PP & $\mathrm{R}_{1}=\mathrm{C}_{6} \mathrm{H}_{5}, \mathrm{R}_{2}=\mathrm{R}_{3}=\mathrm{R}_{4}=\mathrm{R}_{5}=\mathrm{H}$ \\
3-PP & $\mathrm{R}_{1}=\mathrm{R}_{3}=\mathrm{R}_{4}=\mathrm{R}_{5}=\mathrm{H}, \mathrm{R}_{2}=\mathrm{C}_{6} \mathrm{H}_{5}$ \\
4-PP & $\mathrm{R}_{1}=\mathrm{R}_{2}=\mathrm{R}_{4}=\mathrm{R}_{5}=\mathrm{H}, \mathrm{R}_{3}=\mathrm{C}_{6} \mathrm{H}_{5}$ \\
\hline
\end{tabular}

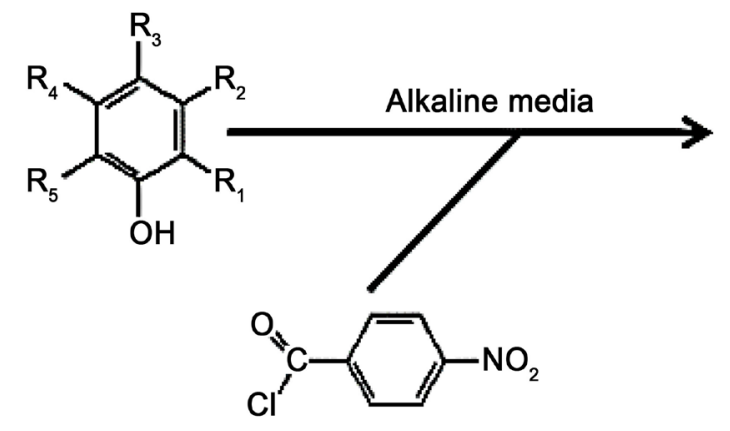

4-NB-Cl<smiles>[R]c1c([R])c([R])c(OC(=O)c2ccc([N+](=O)[O-])cc2)c([R])c1[R]</smiles>

Figure 1. Derivatization of Phenol, five CPs and three PPs with 4-NB-Cl. 
water was collected from our laboratory.

\subsection{Chromatographic Conditions}

The HPLC system consisted of a model LC10-ATvp pump (Shimadzu, Kyoto, Japan), a Rheodyne injection valve (Cotati, CA, U.S.A.) with a $50-\mu \mathrm{L}$ loop, and a model SPD-10Avp UV detector (Shimadzu) operating at $280 \mathrm{~nm}$. The HPLC column (Cholester, Nacalai tesque, Kyoto) was $150 \times 3.0 \mathrm{~mm}$ i.d., containing 5 $\mu \mathrm{m}$ particles. Quantification of peaks was performed using a Chromatopac Model C-R8A integrator (Shimadzu). The mobile phase was prepared by the addition of acetonitrile $(700 \mathrm{~mL})$ to $300 \mathrm{~mL}$ of Milli-Q water containing trifluoroacetic acid $(0.1 \mathrm{v} / \mathrm{v} \%)$. The samples were eluted from the column at room temperature at a flow rate of $0.43 \mathrm{~mL} / \mathrm{min}$.

\subsection{Derivatization}

Ultrapure water was from a Milli-Q water purification system (Simplicity UV, Millipore Corporation, Bedford, MA, U.S.A.). Standard samples of phenol, five $\mathrm{CPs}$, and three PPs were dissolved in Milli-Q water, acetone, and methanol, respectively, to obtain solution concentrations of $1 \mathrm{~g} / \mathrm{L}$. The standard mixture was prepared by dilution as required with Milli- $\mathrm{Q}$ water. Borate buffer $(0.1 \mathrm{M})$ was adjusted to various $\mathrm{pH}$ values by the addition of $\mathrm{NaOH}$. Borate buffer $(100 \mu \mathrm{L})$ was added to Milli-Q water $(100 \mu \mathrm{L})$, and diluted standard samples (100 $\mu \mathrm{L} ; 0$, $0.02,0.04,0.06,0.12,0.36,0.6$, and $0.9 \mathrm{mg} / \mathrm{L}$ ) were added to the mixture. Then, $4-\mathrm{NB}-\mathrm{Cl}$ solution in acetonitrile $(2 \mathrm{mg} / \mathrm{mL}, 100 \mu \mathrm{L})$ was added. The mixture was vortexed and allowed to react at $50^{\circ} \mathrm{C}$, then an aliquot $(50 \mu \mathrm{L})$ was taken and injected into the HPLC system.

\subsection{Application to Water Samples}

Tap water $(100 \mu \mathrm{L})$ instead of Milli-Q water $(100 \mu \mathrm{L})$ was analyzed in the same manner as described above. Relative recovery was expressed as the ratio of the calibration curve prepared from a water sample spiked with the standard sample to the standard calibration curve prepared as described above. Relative recovery data were used to assess the accuracy of the method.

\section{Results and Discussion}

\subsection{Reaction Time Courses of Phenol, Five CPs, and Three PPs with 4-NB-Cl}

For the time course study, the reaction time was set at $0.5,1,2,4,6$, and $10 \mathrm{~min}$ (Figure 2). Phenol, five CPs, and three PPs $(100 \mu \mathrm{L}$, each $0.36 \mathrm{mg} / \mathrm{L})$, borate buffer $(100 \mu \mathrm{L}, \mathrm{pH} 8.5)$, and 4-NB-Cl $(100 \mu \mathrm{L}, 2 \mathrm{mg} / \mathrm{mL})$ were added to Milli-Q water $(100 \mu \mathrm{L})$ and each solution was left to stand for the appropriate time. All derivatizations reached a plateau at 0.5 or $1 \mathrm{~min}$. However, chromatograms of the reaction mixture at $0.5 \mathrm{~min}$ showed a remarkable peak at $4.4 \mathrm{~min}$ (data not shown), which might interfere with the peak of 4-NB-phenol. Thus, the derivatization time of 1 min was selected. 


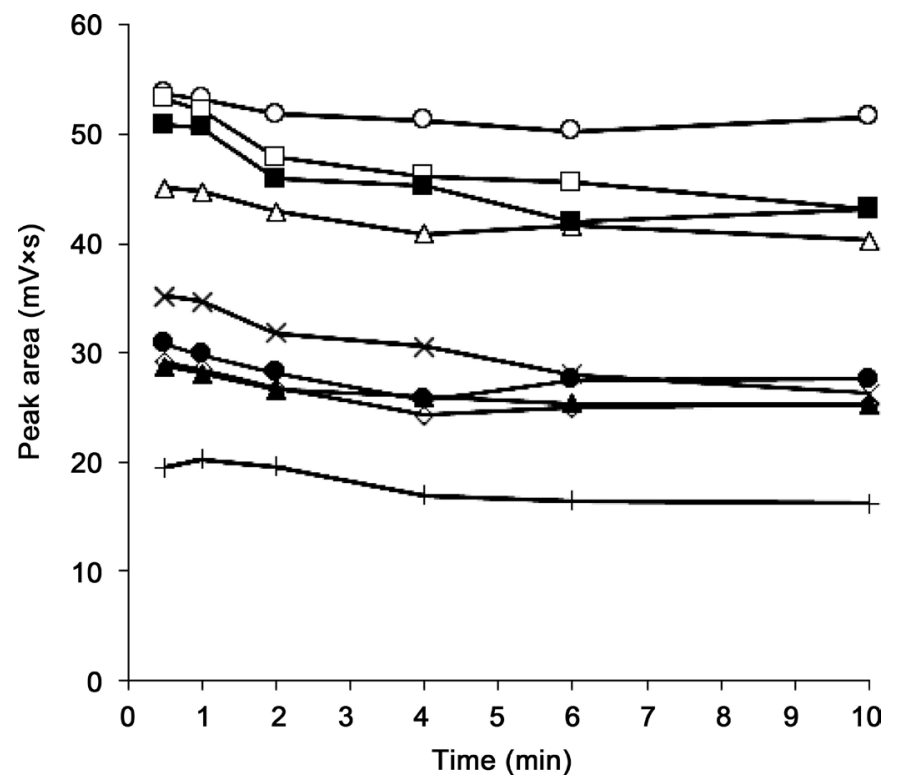

Standard samples (each $0.36 \mathrm{mg} / \mathrm{L}$ ) were reacted with $4-\mathrm{NB}-\mathrm{Cl}$ in borate buffer at $\mathrm{pH} 8.5$ at $50^{\circ} \mathrm{C}$. (०), 4-NB-phenol; $(\Delta)$, 4-NB-4-CP; $(\square)$, 4-NB-2-CP, $(\diamond)$, 4-NB-2,4-DCP; $(\times)$, 4-NB-2,6-DCP; (+),

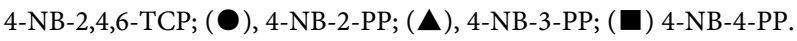

Figure 2. Time courses of formation of 4-NB derivatives of phenol, five CPs, and three PPs.

\section{2. pH Dependency of Derivatization of Phenol, Five CPs, and Three PPs with 4-NB-Cl}

$\mathrm{pH}$ Dependency ( $\mathrm{pH} 8$ to 9.5) was examined at the derivatization time of $1 \mathrm{~min}$ (Figure 3). Peak areas of derivatives, except the phenol derivative, showed little variation in the range of $\mathrm{pH} 8$ or 8.25 to 9 . However, the peak area of 4-NBphenol at $\mathrm{pH} 8$ was markedly reduced because of interference from the peak at $4.4 \mathrm{~min}$. Therefore, $\mathrm{pH} 8.5$ was selected for the derivatization buffer.

\subsection{Chromatogram}

Figure 4 shows typical chromatograms obtained from (a) blank and (b) a standard mixture (each $0.36 \mathrm{mg} / \mathrm{L}$ ) at $\mathrm{pH} 8.5$ for $1 \mathrm{~min}$. The retention times of 4-NB-phenol, 4-NB-2-CP, 4-NB-4-CP, 4-NB-2-PP, 4-NB-2,6-DCP, 4-NB-2,4DCP, 4-NB-3-PP, 4-NB-4-PP, and 4-NB-2,4,6-TCP were 4.9, 6.0, 6.5, 7.4, 8.1, $9.2,10.2,12.2$, and $13.6 \mathrm{~min}$, respectively. The running time was $15 \mathrm{~min}$. Our preliminary test showed that 4-NB-2-PP and 4-NB-2,6-DCP were co-eluted (8.0 $\mathrm{min}$ ) from a $\mathrm{C}_{18}$ column $\left(\mathrm{C}_{18}\right.$-MS-II, Nakalai tesque, $150 \times 3.0 \mathrm{~mm}$ i.d., containing $5 \mu \mathrm{m}$ particles) under the same HPLC conditions. In addition, the peaks of 4-NB-3-PP $(9.7 \mathrm{~min})$ and 4-NB-4-PP (10.0 $\mathrm{min})$ were much closer together than in the case of analysis using the Cholester column. Thus, the Cholester column was found to be more useful for simultaneous determination of the nine tested phenols.

\subsection{Standard Curves of Phenol, Five CPs, and Three PPs}

The standard curves of phenol, five CPs, and three PPs were constructed by 


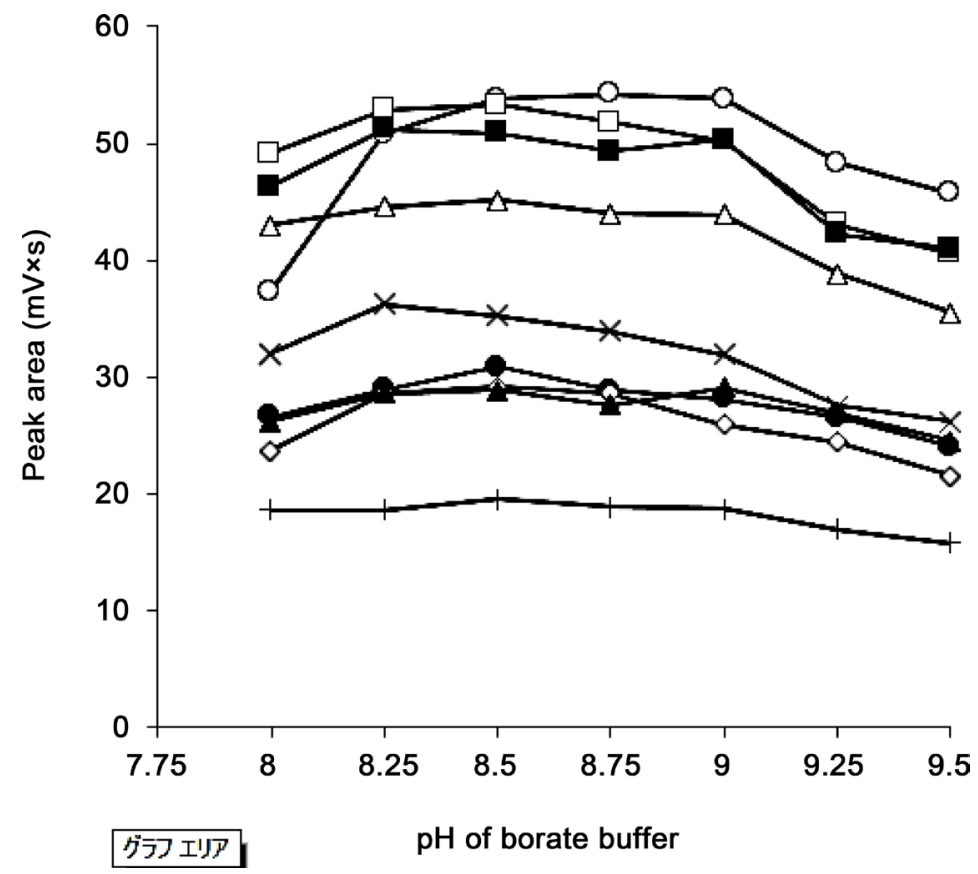

Standard samples (each $0.36 \mathrm{mg} / \mathrm{L}$ ) were reacted with $4-\mathrm{NB}-\mathrm{Cl}$ in borate buffer at $\mathrm{pH} 8.5$ at $50^{\circ} \mathrm{C}$. (०), 4-NB-phenol; $(\Delta)$, 4-NB-4-CP; $(\square)$, 4-NB-2-CP, $(\diamond)$, 4-NB-2,4-DCP; $(\times)$, 4-NB-2,6-DCP; (+), 4-NB-2,4,6-TCP; (๑), 4-NB-2-PP; ( $\boldsymbol{(})$ ), 4-NB-3-PP; (ם) 4-NB-4-PP.

Figure 3. $\mathrm{pH}$ Dependency of the formation of 4-NB derivatives of phenol, five CPs, and three PPs.
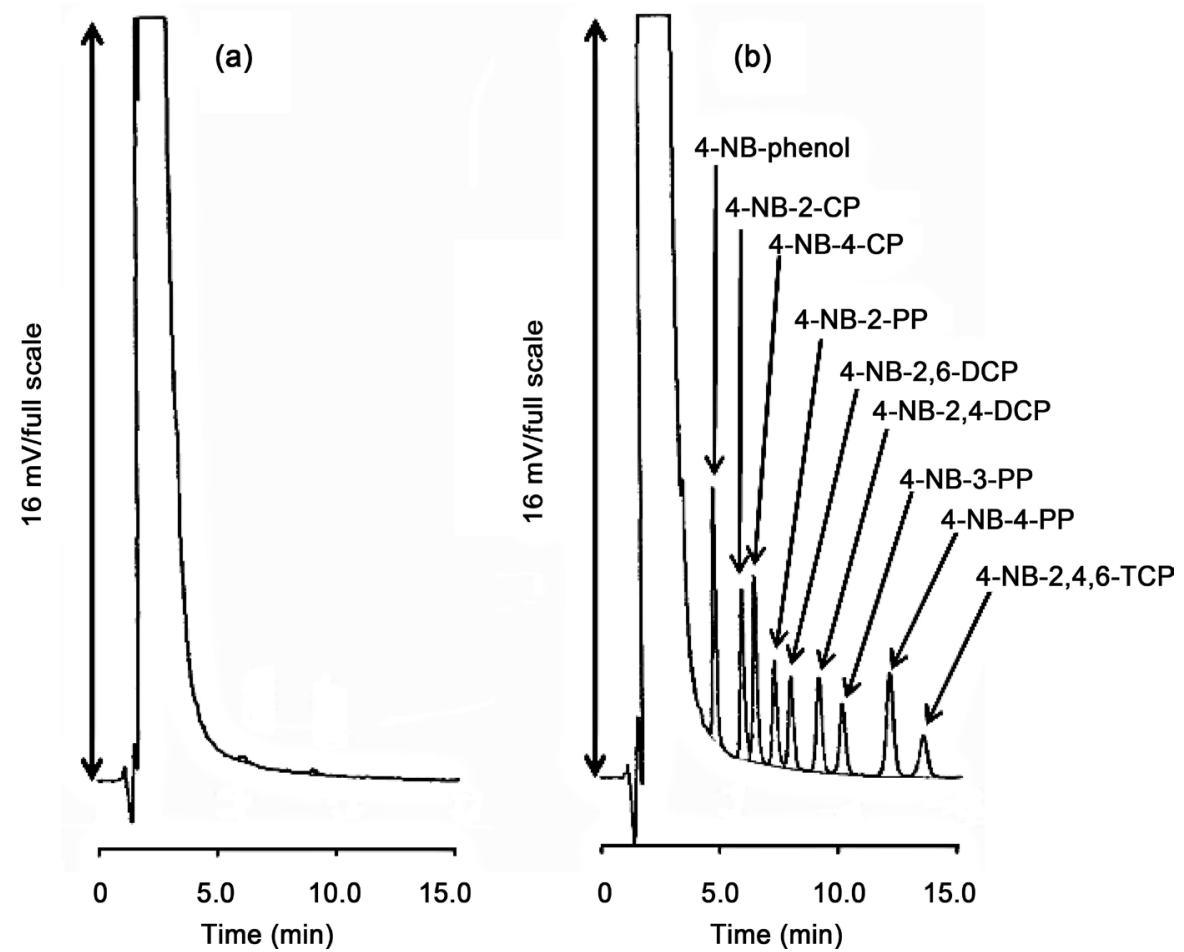

Standard samples (each $0.36 \mathrm{mg} / \mathrm{L}$ ) were reacted with $4-\mathrm{NB}-\mathrm{Cl}$ for $1 \mathrm{~min}$ at $\mathrm{pH} 8.5$ at $50^{\circ} \mathrm{C}$. Retention times (min): 4.9, 4-NB-phenol;6.0, 4-NB-2-CP; 6.5, 4-NB-4-CP, 7.4, 4-NB-2-PP; 8.1, 4-NB-2,6DCP; 9.2, 4-NB-2,4-DCP; 10.2, 4-NB-3-PP; 12.2, 4-NB-4-PP; 13.6 4-NB-2,4,6-TCP.

Figure 4. Typical chromatograms of blank (a) and standard sample ((b), each $0.36 \mathrm{mg} / \mathrm{L})$ after derivatization with 4 -NB-Cl. 
Table 1. Linear correlation parameters.

\begin{tabular}{cccccc}
\hline Compound & Slope & Intercept & Concentration range & $r^{2}$ & Lower limit of detection \\
\hline Phenol & 148 & +0.150 & 0.02 to $0.9 \mathrm{mg} / \mathrm{L}$ & 0.9986 & $0.006 \mathrm{mg} / \mathrm{L}(75 \mathrm{pg})$ \\
2-CP & 123 & +0.813 & 0.06 to $0.9 \mathrm{mg} / \mathrm{L}$ & 0.9959 & $0.02 \mathrm{mg} / \mathrm{L}(250 \mathrm{pg})$ \\
4-CP & 141 & +0.151 & 0.02 to $0.9 \mathrm{mg} / \mathrm{L}$ & 0.9989 & $0.006 \mathrm{mg} / \mathrm{L}(75 \mathrm{pg})$ \\
2,6-DCP & 77.7 & +0.485 & 0.06 to $0.9 \mathrm{mg} / \mathrm{L}$ & 0.9969 & $0.02 \mathrm{mg} / \mathrm{L}(250 \mathrm{pg})$ \\
2,4-DCP & 90.5 & +1.68 & 0.12 to $0.9 \mathrm{mg} / \mathrm{L}$ & 0.9928 & $0.05 \mathrm{mg} / \mathrm{L}(625 \mathrm{pg})$ \\
2,4,6-TCP & 56.4 & +0.211 & 0.04 to $0.9 \mathrm{mg} / \mathrm{L}$ & 0.9975 & $0.02 \mathrm{mg} / \mathrm{L}(250 \mathrm{pg})$ \\
2-PP & 82.2 & +0.142 & 0.04 to $0.9 \mathrm{mg} / \mathrm{L}$ & 0.9993 & $0.01 \mathrm{mg} / \mathrm{L}(125 \mathrm{pg})$ \\
3-PP & 78.7 & +0.209 & 0.04 to $0.9 \mathrm{mg} / \mathrm{L}$ & 0.9945 & $0.01 \mathrm{mg} / \mathrm{L}(125 \mathrm{pg})$ \\
4-PP & 141 & +0.141 & 0.02 to $0.9 \mathrm{mg} / \mathrm{L}$ & 0.9981 & $0.008 \mathrm{mg} / \mathrm{L}(100 \mathrm{pg})$
\end{tabular}

Values in parenthesis are absolute amounts (pg).

plotting integrated peak area vs. concentration. The calibration data are summarized in Table 1. Plots were all linear in the range of $0.02 \sim 0.12$ to $0.9 \mathrm{mg} / \mathrm{L}$, with $r^{2}$ values $\geq 0.9928$. The values of the lower limit of quantification were the lowest concentration on the standard curve. Their values were $0.02,0.06,0.02$, $0.06,0.12,0.04,0.04,0.04$, and $0.002 \mathrm{mg} / \mathrm{L}$ for phenol, 2-CP, 4-CP, 2,6-DCP, 2,4-DCP, 2,4,6-TCP, 2-PP, 3-PP, and 4-PP, respectively. The lower limits of detection for phenol, $2-\mathrm{CP}$, and $4-\mathrm{CP}$ were estimated as the concentrations giving a detectable peak, since these peaks were located close to a large blank peak. The lower limits of detection for 2,4-DCP, 2,6-DCP, 2,4,6-TCP, 2-PP, 3-PP, and 4-PP were taken to be the concentrations giving a signal-to-noise ratio of 3:1. The lower limits of detection were 0.006 (75 pg), $0.02(250 \mathrm{pg}), 0.006$ (75 pg), 0.02 (250 pg), 0.05 (625 pg), 0.02 (250 pg), 0.01 (125 pg), 0.01 (125 pg), and 0.008 (100 pg) $\mathrm{mg} / \mathrm{L}$ for phenol, 2-CP, 4-CP, 2,6-DCP, 2,4-DCP, 2,4,6-TCP, 2-PP, $3-\mathrm{PP}$, and 4-PP, respectively. Values in parenthesis are the detection limits in terms of absolute amounts. The sensitivity for phenol and CPs was slightly inferior to that in our previous study (absolute amount of 67 to $167 \mathrm{pg}$ ) [19]. In addition, the detection limit of 2-PP (125 pg) represents only moderate sensitivity compared with previous reports (range of 3.4 to $350 \mathrm{pg}$ ) [8] [9] [26] [27]. Detection limits of 3-PP and 4-PP have not been reported.

\subsection{Precision and Accuracy}

Precision and accuracy for intra-day and inter-day assays of these derivatives are shown in Table 2 and Table 3. In the intra-day assay, the range of standard deviation was within $2.6 \%$ to $11.1 \%$ of the mean. Recoveries were within the range of $87.5 \%$ to $105.2 \%$. In the inter-day assay, the range of standard deviation was within $4.2 \%$ to $12.0 \%$ of the mean. Recoveries were within the range of $88.5 \%$ to $104.1 \%$.

\subsection{Environmental Analysis}

The described method was used to determine phenol, five CPs, and three PPs in tap water and spiked tap water. As shown in Table 4, the levels of phenol, five 
Table 2. Intra-day assay reproducibility for determination of phenol, five CPs, and three PPs.

\begin{tabular}{|c|c|c|c|c|}
\hline \multicolumn{2}{|c|}{ Compound (mg/L) } & \multirow{2}{*}{$\begin{array}{c}\text { Measured (mg/L, Mean } \pm \text { S.D., } n=5) \\
0.0178 \pm 0.0017\end{array}$} & \multirow{2}{*}{$\begin{array}{c}\text { C.V. }(\%) \\
9.6\end{array}$} & \multirow{2}{*}{$\begin{array}{c}\text { Recovery (\%) } \\
89.0\end{array}$} \\
\hline Phenol & 0.02 & & & \\
\hline & 0.9 & $0.857 \pm 0.027$ & 3.2 & 95.2 \\
\hline \multirow[t]{2}{*}{$2-\mathrm{CP}$} & 0.06 & $0.0533 \pm 0.0041$ & 7.7 & 88.8 \\
\hline & 0.9 & $0.901 \pm 0.032$ & 3.6 & 100.1 \\
\hline \multirow[t]{2}{*}{$4-\mathrm{CP}$} & 0.02 & $0.0175 \pm 0.0018$ & 10.3 & 87.5 \\
\hline & 0.9 & $0.947 \pm 0.030$ & 3.2 & 105.2 \\
\hline \multirow[t]{2}{*}{ 2,6-DCP } & 0.06 & $0.0552 \pm 0.0049$ & 8.9 & 92.0 \\
\hline & 0.9 & $0.919 \pm 0.030$ & 3.3 & 102.1 \\
\hline \multirow[t]{2}{*}{$2,4-\mathrm{DCP}$} & 0.12 & $0.114 \pm 0.010$ & 8.8 & 95.0 \\
\hline & 0.9 & $0.866 \pm 0.025$ & 2.9 & 96.2 \\
\hline \multirow[t]{2}{*}{ 2,4,6-ТCP } & 0.04 & $0.0359 \pm 0.0040$ & 11.1 & 89.8 \\
\hline & 0.9 & $0.839 \pm 0.031$ & 3.7 & 93.2 \\
\hline \multirow[t]{2}{*}{ 2-PP } & 0.04 & $0.0366 \pm 0.0040$ & 10.9 & 91.5 \\
\hline & 0.9 & $0.884 \pm 0.023$ & 2.6 & 98.2 \\
\hline \multirow[t]{2}{*}{ 3-PP } & 0.04 & $0.0364 \pm 0.0037$ & 10.2 & 91.0 \\
\hline & 0.9 & $0.914 \pm 0.037$ & 4.0 & 101.6 \\
\hline \multirow[t]{2}{*}{ 4-PP } & 0.02 & $0.0184 \pm 0.0017$ & 9.2 & 92.0 \\
\hline & 0.9 & $0.920 \pm 0.027$ & 2.9 & 102.2 \\
\hline
\end{tabular}

Table 3. Inter-day assay reproducibility for determination of phenol, five CPs, and three PPs.

\begin{tabular}{|c|c|c|c|c|}
\hline \multicolumn{2}{|c|}{ Compound (mg/L) } & \multirow{2}{*}{$\begin{array}{c}\text { Measured }(\mathrm{mg} / \mathrm{L}, \text { Mean } \pm \text { S.D., } n=5) \\
0.0177 \pm 0.0018\end{array}$} & \multirow{2}{*}{$\begin{array}{c}\text { C.V. (\%) } \\
10.2\end{array}$} & \multirow{2}{*}{$\begin{array}{c}\text { Recovery (\%) } \\
88.5\end{array}$} \\
\hline Phenol & 0.02 & & & \\
\hline & 0.9 & $0.850 \pm 0.039$ & 4.6 & 94.4 \\
\hline \multirow[t]{2}{*}{$2-\mathrm{CP}$} & 0.06 & $0.0538 \pm 0.0054$ & 10.0 & 89.7 \\
\hline & 0.9 & $0.924 \pm 0.041$ & 4.4 & 102.7 \\
\hline \multirow[t]{2}{*}{$4-\mathrm{CP}$} & 0.02 & $0.0176 \pm 0.0020$ & 11.4 & 88.0 \\
\hline & 0.9 & $0.925 \pm 0.045$ & 4.9 & 102.8 \\
\hline \multirow[t]{2}{*}{ 2,6-DCP } & 0.06 & $0.0536 \pm 0.0055$ & 10.3 & 89.3 \\
\hline & 0.9 & $0.932 \pm 0.040$ & 4.3 & 103.6 \\
\hline \multirow[t]{2}{*}{ 2,4-DCP } & 0.12 & $0.109 \pm 0.013$ & 11.9 & 90.8 \\
\hline & 0.9 & $0.902 \pm 0.038$ & 4.2 & 100.2 \\
\hline \multirow[t]{2}{*}{ 2,4,6-ТCP } & 0.04 & $0.0354 \pm 0.0040$ & 11.3 & 88.5 \\
\hline & 0.9 & $0.866 \pm 0.045$ & 5.2 & 96.2 \\
\hline \multirow[t]{2}{*}{ 2-PP } & 0.04 & $0.0368 \pm 0.0043$ & 11.7 & 92.0 \\
\hline & 0.9 & $0.859 \pm 0.057$ & 6.6 & 95.4 \\
\hline \multirow[t]{2}{*}{ 3-PP } & 0.04 & $0.0358 \pm 0.0043$ & 12.0 & 89.5 \\
\hline & 0.9 & $0.937 \pm 0.061$ & 6.5 & 104.1 \\
\hline \multirow[t]{2}{*}{$4-\mathrm{PP}$} & 0.02 & $0.0182 \pm 0.0021$ & 11.5 & 91.0 \\
\hline & 0.9 & $0.914 \pm 0.058$ & 6.3 & 101.6 \\
\hline
\end{tabular}


Table 4. Levels of phenol, five CPs, and three PPs in tap water, and relative recovery values.

\begin{tabular}{cccc}
\hline Compound & $\begin{array}{c}\text { Concentration in tap water } \\
(\%, \text { mean } \pm \text { S.D., } n=4)\end{array}$ & Relative recovery & $I^{2}$ (Average) \\
\hline Phenol & N.D. & $94.4 \pm 6.2$ & 0.9993 \\
2-CP & N.D. & $105.9 \pm 3.9$ & 0.9972 \\
4-CP & N.D. & $109.2 \pm 8.5$ & 0.9982 \\
2,6-DCP & N.D. & $94.9 \pm 4.2$ & 0.9961 \\
2,4-DCP & N.D. & $109.0 \pm 8.7$ & 0.9932 \\
2,4,6-TCP & N.D. & $107.3 \pm 6.8$ & 0.9964 \\
2-PP & N.D. & $104.3 \pm 5.6$ & 0.9989 \\
3-PP & N.D. & $107.0 \pm 6.2$ & 0.9941 \\
4-PP & N.D. & $107.5 \pm 5.3$ & 0.9956 \\
\hline
\end{tabular}

N.D., not determined.

CPs, and three PPs in tap water were below the lower limit of quantification. Calibration curves prepared from tap water samples spiked with phenol, five CPs, and three PPs showed linear relationships between concentration and peak response, with $r^{2} \geq 0.9932$, and the relative recovery values were $94.4 \%$ to $109.2 \%$. These results indicate that our method is capable of monitoring tap water for contamination with phenol, CPs, and/or PPs.

\section{Conclusion}

We have developed an HPLC-UV method using a Cholester column for simultaneous determination of nine compounds (phenol, 2-CP, 4-CP, 2,4-DCP, 2,6DCP, 2,4,6-TCP, 2-PP, 3-PP, and 4-PP) in tap water by using $4-\mathrm{NB}-\mathrm{Cl}$ as a UV-labeling reagent, without complicated sample clean-up. The fast derivatization, the inexpensive reagent, and the short running time were shown in this paper. The presented system is simple and suitable for monitoring or routine testing of tap water for contamination with the test compounds (phenol, five CPs, and/or three PPs), i.e., for assessing compliance with official guidelines.

\section{References}

[1] World Health Organization (2006) Guidelines for Drinking-Water Quality Incorporating First Addendum. Volume 1, Recommendations. 3rd Edition, 329-331.

[2] Llompart, M., Lourido, M., Landin, P., García-Jares, C. and Cela, R. (2002) Optimization of a Derivatization-Solid-Phase Microextraction Method for the Analysis of Thirty Phenolic Pollutants in Water Samples. Journal of Chromatography A, 963, 137-148.

[3] González-Toledo, E., Prat, M.D. and Alpendurada, M.F. (2001) Solid-Phase Microextraction Coupled to Liquid Chromatography for the Analysis of Phenolic Compounds in Water. Journal of Chromatography A, 923, 45-52.

[4] Asan, A. and Isildak, I. (2003) Determination of Major Phenolic Compounds in Water by Reversed-Phase Liquid Chromatography after Pre-Column Derivatization with Benzoyl Chloride. Journal of Chromatography A, 988, 145-149. 
[5] Davoren, M. and Fogarty, A.M. (2006) In Vitro Cytotoxicity Assessment of the Biocidal Agents Sodium $O$-Phenylphenol, Sodium $O$-Benzyl- $P$-Chlorophenol, and Sodium $P$-Tertiary Amylphenol Using Established Fish Cell Lines. Toxicology in $\mathrm{Vi}^{-}$ tro, 20, 1190-1201.

[6] Kolbe, N. and Andersson, J.T. (2006) Simple and Sensitive Determination of $O$ Phenylphenol in Citrus Fruits Using Gas Chromatography with Atomic Emission or Mass Spectrometric Detection. Journal of Agriculture and Food Chemistry, 54, 5736-5741. https://doi.org/10.1021/jf060753q

[7] Bomhard, E.M., Brendler-Schwaab, S.Y., Freyberger, A., Herbold, B.A., Leser, K.H. and Richter, M. (2002) O-Phenylphenol and Its Sodium and Potassium Salts: A Toxicological Assessment. Critical Reviews in Toxicology, 32, 551-626. https://doi.org/10.1080/20024091064318

[8] Thompson, R.D. (2001) Determination of Phenolic Disinfectant Agents in Commercial Formulation by Liquid Chromatography. Journal of Association of Official Analytical Chemists International, 84, 815-822.

[9] Yang, L., Kotani, A., Hakamata, H. and Kusu, F. (2004) Determination of Ortho-Phenylphenol Residues in Lemon Rind by High-Performance Liquid Chromatography with Electrochemical Detection Using a Microbore Column. Analytical Sciences, 20, 199-203. https://doi.org/10.2116/analsci.20.199

[10] World Health Organization (2006) Guidelines for Drinking-Water Quality Incorporating First Addendum. Volume 1, Recommendations. 3rd Edition, 427-428.

[11] Farino, J., Norwitz, G., Boyko, W.J. and Keliher, P.N. (1981) Study of the Behaviour of Various Phenolic Compounds in the 4-Aminoantipyrine and Ultraviolet-Ratio Spectrophotometric Methods without and with Distillation. Talanta, 28, 705-708.

[12] Rodriguez-Alcala, M., Yañez-Sedeño, P. and Diez, L.M. (1988) Determination of Pentachlorophenol by Flow-Injection Analysis with Spectrophotometric Detection. Talanta, 35, 601-604.

[13] Ito, R., Kawaguchi, M., Honda, H., Koganei, Y., Okanouchi, N., Sakui, N., Saito, K. and Nakazawa, H. (2008) Hollow-Fiber-Supported Liquid Phase Microextraction with in Situ Derivatization and Gas Chromatography-Mass Spectrometry for Determination of Chlorophenols in Human Urine Samples. Journal of Chromatography $B, 872,63-67$.

[14] Almeda, S., Nozal, L., Arce, L. and Valcárcel, M. (2007) Direct Determination of Chlorophenols Present in Liquid Samples by Using a Supported Liquid Membrane Coupled In-Line with Capillary Electrophoresis Equipment. Analytica Chimica Acta, 587, 97-103.

[15] Tsukagoshi, K., Kameda, T., Yamamoto, M. and Nakajima, R. (2002) Separation and Determination of Phenolic Compounds by Capillary Electrophoresis with Chemiluminescence Detection. Journal of Chromatography A, 978, 213-220.

[16] Suliman, F.E., Al-Kindi, S.S., Al-Kindy, S.M. and Al-Lawati, H.A. (2006) Analysis of Phenols in Water by High-Performance Liquid Chromatography Using Coumarin-6-Sulfonyl Chloride as a Fluorogenic Precolumn Label. Journal of Chromatography $A, 1101,179-184$.

[17] Ruiz-Jiménez, J. and Luque de Castro, M.D. (2007) In-Column Micro-High-Performance Liquid Chromatographic Concentration-Separation Prior to Ultraviolet Detection for the Determination of Chlorophenols in Water Samples. Journal of Chromatography $A, 1174,78-84$.

[18] Fattahi, N., Assadi, Y., Hosseini, M.R. and Jahromi, E.Z. (2007) Determination of Chlorophenols in Water Samples Using Simultaneous Dispersive Liquid-Liquid Microextraction and Derivatization Followed by Gas Chromatography-Electron- 
Capture Detection. Journal of Chromatography A, 1157, 23-29.

[19] Higashi, Y. and Fujii, Y. (2009) HPLC-UV Analysis Of Phenol and Chlorophenols in Water After Pre-Column Derivatization with 4-Fluoro-7-nitro-2,1,3-benzoxadiazole. Journal of Liquid Chromatography \& Related Technologies, 32, 2372-2383. https://doi.org/10.1080/10826070903188013

[20] Wada, M., Kinoshita, S., Itayama, Y., Kuroda, N. and Nakashima, K. (1999) Sensitive High-Performance Liquid Chromatographic Determination with Fluorescence Detection of Phenol and Chlorophenols with 4-(4,5-Diphenyl-1 $H$-imidazol-2-yl) Benzoyl Chloride as a Labeling Reagent. Journal of Chromatography B, 721, 179186.

[21] Orejuela, E. and Silva, M. (2002) Sensitive Determination of Low Molecular Mass Phenols by Liquid Chromatography with Chemiluminescence Detection for the Determination of Phenol and 4-Methylphenol in Urine. Analyst, 127, 1433-1439. https://doi.org/10.1039/b207321h

[22] Zhang, L., Zhang, L., Zhang, W. and Zhang, Y. (2005) Analysis of Phenols by HighPerformance Liquid Chromatography with Pre-Column Derivatization by 2-(9-Carbazole)-ethyl-chloroformate. Analytica Chimica Acta, 543, 52-57.

[23] Higashi, Y. (2016) Development of Simultaneous HPLC-Fluorescence Assay of Phenol and Chlorophenols in Tap Water after Pre-Column Derivatization with 3-Chlorocarbonyl-6,7-dimethoxy-1-methyl-2(1H)-quinoxalinone. Detection, 4, 1624. https://doi.org/10.4236/detection.2016.41003

[24] Higashi, Y. and Fujii, Y. (2015) Determination of Three Phenylphenols in Grapefruit Juice by High-Performance Liquid Chromatography after Pre-Column Derivatization with 4-Fluoro-7-nitro-2,1,3-benzoxadiazole. Journal of Analytical Chemistry, 70, 346-350. https://doi.org/10.1134/S1061934815030235

[25] Higashi, Y. and Konno, K. (2015) Simple Determination of $o$-Phenylphenol in Skin Lotion by High-Performance Liquid Chromatography Coupled with Fluorescence Detection after Pre-Column Derivatization with 4-( $N$-Chloroformylmethyl- $N$-methylamino)-7-nitro-2,1,3-benzoxadiazole. Journal of Cosmetic. Science, 66, 129-137.

[26] Yamazaki, Y. and Ninomiya, T. (1999) Determination of Benomyl, Diphenyl, $o$-Phenylphenol, Thiabendazole, Chlorpyrifos, Methidathion, and Methyl Parathion in Oranges by Solid-Phase Extraction, Liquid Chromatography, and Gas Chromatography. Journal of AOAC International, 82, 1474-1478.

[27] Blasco, C., Picó, Y., Mañes, J. and Font, G. (2002) Determination of Fungicide Residues in Fruits and Vegetables by Liquid Chromatography-Atmospheric Pressure Chemical Ionization Mass Spectrometry. Journal of Chromatography A, 947, 227 235. 
Submit or recommend next manuscript to SCIRP and we will provide best service for you:

Accepting pre-submission inquiries through Email, Facebook, LinkedIn, Twitter, etc. A wide selection of journals (inclusive of 9 subjects, more than 200 journals)

Providing 24-hour high-quality service

User-friendly online submission system

Fair and swift peer-review system

Efficient typesetting and proofreading procedure

Display of the result of downloads and visits, as well as the number of cited articles Maximum dissemination of your research work

Submit your manuscript at: http://papersubmission.scirp.org/

Or contact jasmi@scirp.org 